\title{
Community-specific hydraulic conductance potential of soil water decomposed for two Alpine grasslands by small-scale lysimetry
}

\author{
Georg Frenck $^{1,2}$, Georg Leitinger ${ }^{1,2}$, Nikolaus Obojes ${ }^{1}$, Magdalena Hofmann ${ }^{2}$, Christian Newesely ${ }^{2}$, \\ Mario Deutschmann ${ }^{2}$, Ulrike Tappeiner ${ }^{1,2}$, and Erich Tasser ${ }^{1}$ \\ ${ }^{1}$ Institute for Alpine Environment, EURAC research, Viale Druso 1, 39100 Bozen/Bolzano, Italy \\ ${ }^{2}$ Institute of Ecology, University of Innsbruck, Sternwartestrasse 15, 6020 Innsbruck, Austria
}

Correspondence: Erich Tasser (erich.tasser@eurac.edu)

Received: 16 June 2017 - Discussion started: 7 July 2017

Revised: 22 December 2017 - Accepted: 15 January 2018 - Published: 21 February 2018

\begin{abstract}
For central Europe in addition to rising temperatures an increasing variability in precipitation is predicted. This will increase the probability of drought periods in the Alps, where water supply has been sufficient in most areas so far. For Alpine grasslands, community-specific imprints on drought responses are poorly analyzed so far due to the sufficient natural water supply. In a replicated mesocosm experiment we compared evapotranspiration (ET) and biomass productivity of two differently drought-adapted Alpine grassland communities during two artificial drought periods divided by extreme precipitation events using highprecision small lysimeters. The drought-adapted vegetation type showed a high potential to utilize even scarce water resources. This is combined with a low potential to translate atmospheric deficits into higher water conductance and a lower biomass production as those measured for the nondrought-adapted type. The non-drought-adapted type, in contrast, showed high water conductance potential and a strong increase in ET rates when environmental conditions became less constraining. With high rates even at dry conditions, this community appears not to be optimized to save water and might experience drought effects earlier and probably more strongly. As a result, the water use efficiency of the drought-adapted plant community is with $2.6 \mathrm{~g}_{\mathrm{DW}} \mathrm{kg}^{-1}$ of water much higher than that of the non-drought-adapted plant community $\left(0.16 \mathrm{~g}_{\mathrm{DW} \mathrm{kg}} \mathrm{kg}^{-1}\right)$. In summary, the vegetation's reaction to two covarying gradients of potential evapotranspiration and soil water content revealed a clear difference in vegetation development and between water-saving and water-spending strategies regarding evapotranspiration.
\end{abstract}

\section{Introduction}

Comprehensive alterations in the climate system of the Earth are projected for the future decades. Due to increased greenhouse gas concentrations in the atmosphere, the global average temperature is predicted to rise. These changes in the energy budget of the atmosphere are suggested to propagate alterations in atmospheric circulation and modify precipitation patterns worldwide (IPCC, 2013; Knapp et al., 2008; Solomon et al., 2009). Such variations can result in changes in the spatial distribution of precipitation and thereby affect average values of rainfall locally. However, concurrent changes in the temporal occurrence of rainfall events are predicted to increase the variability in rainfall with longer intervals in between and more extreme events. This will lead to stronger variability in soil water availability and longer droughts (IPCC, 2013, 2012).

The water balance in terrestrial ecosystems is dominantly controlled by plant processes. It is suggested that up to $55 \%$ of the terrestrial water loss to the atmosphere is mediated through plant transpiration (Wang et al., 2014; Wei et al., 2017). Consequently, it is assumed that plants will experience drought stress more frequently, which may constrain primary productivity as it is substantially controlled by the supply of water (Knapp et al., 2008). These direct effects of limited water provision to the system will be accompanied by increased water demand in a warmer world, leading to more negative water balances, which will accentuate drought effects on vegetation processes (Heimann and Reichstein, 2008). However, the structure and functionality of the ecosystems - defining rates of evapotranspiration are also subject to local climatic conditions. Hence, a direct 
feedback mechanism is established, which might amplify or dampen the global and local consequences of climatic change on ecosystems (Heimann and Reichstein, 2008).

Defining biomass productivity-precipitation relationships of ecosystems is of main interest because functional changes in the soil-plant-atmosphere interface, which controls water fluxes into the atmosphere, will inherently be affected by the manifestation of these relationships. However, beyond the direct implications of limited water availability on biomass production and growth, indirect mechanisms define this relationship. The abundance of individual plant species in the plant community results in a change in functional structure of that community, optimizing water use according to different life-history strategies by competitive interactions (Peñuelas et al., 2004). In turn, immediate vegetation responses to fluctuations in precipitation patterns and the strength of interaction with productivity functions will strongly depend on the functional composition of the plant community and ecosystem considered. Therefore, intrinsic characteristics of vegetation will impose another layer of complexity for defining the interactive feedbacks in the relationship between water budget and productivity.

The impact of shifting precipitation regimes can only be predicted inaccurately if the crucial components of the ecosystem water budget - soils, plants and the atmosphere - are evaluated separately and isolated. Due to the complex interactions and processes on different spatiotemporal scales the response of ecosystems to shifts in the water regime is preferably examined in an integrative manner on the system level (Silva, 2015). Manipulative experiments are a well-suited option for investigating the effects imposed by changes in precipitation frequency and intensity below and above the natural range on the ecosystem level (Estiarte et al., 2016). Since we currently lack the knowledge needed to validate the projections for consequences of future changes in rainfall regimes, insights from such integrative investigations are highly valuable for providing important benchmarks of model-based assessments (Estiarte et al., 2016).

Numerous studies have been performed to reveal the responses of temperate grasslands to climatic changes and droughts (Poorter et al., 201; Reichstein et al., 2013). While investigations on responses of above- and belowground carbon fluxes have targeted Alpine systems (Bahn et al., 2009; Hasibeder et al., 2015; Ingrisch et al., 2017), only few studies have addressed components of the ecosystem water budget (De Boeck et al., 2016). While the Alps have not often experienced droughts during the past centuries (van der Schrier et al., 2007), the region has undergone exceptionally fast climatic changes during the late 19th through early 21 st century (Auer et al., 2007; Beniston, 2005; Böhm et al., 2001; Ciccarelli et al., 2008; Rebetez and Reinhard, 2008). Water, especially in the light of future climatic changes in the European Alps in the next 100 years (IPCC, 2007), is already seen as a limited and valuable resource with the potential for socioeconomic conflicts. Therefore, the importance of agricultural management with a potentially higher water demand as a consequence of sprinkling becomes evident. Considering the fundamental role Alpine systems have in water accumulation and freshwater supply for large parts of Europe (Messerli et al., 2004; Viviroli et al., 2003), it seems surprising that the responses of ecosystems in the Alps to changes in precipitation have not drawn more scientific attention. However, while projections suggest only moderate variations in yearly average rainfall in the Alps, significant alterations within the temporal occurrence of rainfall events with a decrease in summer precipitation and increases from winter through spring are implied (Beniston, 2012; Beniston et al., 2007). The decrease in water supply during warmer summer months will potentially increase the frequency and intensity of drought events in the near and distant future in Alpine ecosystems (Gobiet et al., 2014).

The lysimeter methodology is particularly appropriate to unravel the water fluxes along the interface between soil, plants and the atmosphere. It also allows us to decompose the driving subprocesses: evapotranspiration (ET), precipitation $(P)$ and drainage below the rooting zone (Peters et al., 2014). Even quantifying interception would be possible by comparing the increase in lysimeter weight and soil water content during precipitation. This was, however, not a focus of this experiment as interception is estimated to account for less than $10 \%$ of rainfall during the growing season based on Wohlfahrt et al. (2006). By avoiding systematic errors to which traditional measurement systems are prone, the determination of the net water balance is highly accurate and robust (Schrader et al., 2013). If embedded into a surrounding ecosystem, automated lysimeter units, which do not need access to perform manual weighing, measure water fluxes with a minimum of disturbance to the natural boundary layer and microclimatic conditions. Such implementations of autonomous weighable high-precision lysimeters provide unprecedented realism for the description of ecosystem water balances, especially when the filling of the lysimeters was performed to maintain natural soil layering and the connectivity of pores, while keeping potential impacts on the plant community low. Over recent years, several of these units have been established over Europe; for example, a network of 126 lysimeters at 12 sites has been established to monitor climate-change-induced alterations in hydrological cycling within the TERENO (TERrestrial ENvironmental Obsercatories) project in Germany (Bogena et al., 2006; Zacharias et al., 2011). However, the large dimensions (1 $\mathrm{m}$ in diameter or volume) and the corresponding economic efforts for their establishment mostly eliminated the possibility of replicated manipulative experiments employing fully integrated lysimeters.

In a transplantation experiment we used a network of automated small-scale lysimeters to uncover plant-communityspecific differences in the temporal dynamics of soil water depletion and evapotranspiration. A drought-adapted and a non-drought-adapted Alpine grassland community were sub- 
Table 1. Summary of site conditions and vegetation properties.

\begin{tabular}{|c|c|c|c|c|c|c|}
\hline Site & \multicolumn{3}{|c|}{$\begin{array}{c}\text { Stubai }(\mathrm{S}) \text { - study site location } \\
\text { (non-drought-adapted } \\
\text { vegetation) }\end{array}$} & \multicolumn{3}{|c|}{$\begin{array}{c}\text { Matsch/Mazia }(\mathrm{M}) \text { - transplant } \\
\text { origin (drought-adapted } \\
\text { vegetation) }\end{array}$} \\
\hline Municipality & \multicolumn{3}{|c|}{$\begin{array}{l}\text { Neustift im Stubaital, } \\
\text { Wipptal, Austria }\end{array}$} & \multicolumn{3}{|c|}{ Mals/Malles, Vinschgau, Italy } \\
\hline $\begin{array}{l}\text { Elevation/altitude } \\
\text { (m a.s.c.) }\end{array}$ & \multicolumn{3}{|c|}{970} & \multicolumn{3}{|c|}{1570} \\
\hline Longitude, latitude & \multirow{2}{*}{\multicolumn{3}{|c|}{$\begin{array}{c}47^{\circ} 07 ’ 05 ” \mathrm{~N}, 11^{\circ} 19^{\prime} 17^{\prime} \mathrm{E} \\
6.5\end{array}$}} & \multicolumn{3}{|c|}{$46^{\circ} 41^{\prime} 19^{\prime \prime} \mathrm{N}, 10^{\circ} 34^{\prime} 42^{\prime \prime} \mathrm{E}$} \\
\hline $\begin{array}{l}\text { Average annual } \\
\text { temperature }\left({ }^{\circ} \mathrm{C}\right)\end{array}$ & & & & & 6.6 & \\
\hline $\begin{array}{l}\text { Average annual } \\
\text { precipitation }(\mathrm{mm})\end{array}$ & \multicolumn{3}{|c|}{1097.0} & \multicolumn{3}{|c|}{526.7} \\
\hline $\begin{array}{l}\text { Growing season length } \\
\text { (no. of days } \\
\text { with average } \\
\text { temperature of } \\
\text { at least } 5^{\circ} \mathrm{C} \text { ) }\end{array}$ & \multicolumn{3}{|c|}{224} & \multicolumn{3}{|c|}{190} \\
\hline Land use & \multirow{3}{*}{\multicolumn{3}{|c|}{$\begin{array}{l}\text { hay meadow, three cuts } \mathrm{yr}^{-1} \\
\text { fertilized with cow dung } \\
\text { gleyed Cambisol (A-Bv-Go) } \\
\text { loamy sand to sandy silt }\end{array}$}} & \multirow{3}{*}{\multicolumn{3}{|c|}{$\begin{array}{l}\text { hay meadow, two cuts } \mathrm{yr}^{-1} / \\
\text { fertilized with cow dung } \\
\text { Cambisol (Ah-Bv-C) } \\
\text { loam to sandy loam }\end{array}$}} \\
\hline Soil type & & & & & & \\
\hline Soil classification & & & & & & \\
\hline \multicolumn{7}{|c|}{ Soil physical parameters in different soil depth } \\
\hline \multicolumn{7}{|l|}{ Soil texture $(\%)$} \\
\hline Sand & 31 & 31 & 34 & 25 & 34 & 40 \\
\hline Silt & 58 & 63 & 61 & 43 & 45 & 43 \\
\hline Clay & 11 & 6 & 6 & 32 & 21 & 17 \\
\hline $\begin{array}{l}\text { Soil organic matter } \\
\text { content }(\%)\end{array}$ & 3.6 & 1.3 & 0.7 & 7.4 & 3.9 & 2.3 \\
\hline $\begin{array}{l}\text { Plant-available } \\
\text { water (vol \%) }\end{array}$ & 32 & 39 & 39 & 34 & 33 & 27 \\
\hline $\begin{array}{l}\text { Phytosociological } \\
\text { classification }\end{array}$ & Alopecuret & $\begin{array}{l}\text { Poo trivialis - } \\
\mathrm{Im} \text { pratensis }\end{array}$ & gel 1925) & & $\begin{array}{l}\text { Ranunculo bu } \\
\text { rhenatherum ( }\end{array}$ & \\
\hline $\begin{array}{l}\text { Species inventory } \\
\text { (responsible for } 90 \% \\
\text { of total plant cover } \\
\text { in the lysimeter) }\end{array}$ & $\begin{array}{r}\text { Achillea } \\
\text { Pimpine } \\
\text { Ranuncul } \\
\text { Taı } \\
T\end{array}$ & $\begin{array}{l}\text { illefolium, } \mathrm{Ca} \\
\text { la major, Poa } \\
\text { is acris, Rume } \\
\text { uxacum officin } \\
\text { ifolium praten }\end{array}$ & $\begin{array}{l}\text { Im carvi, } \\
\text { ivialis, } \\
\text { acetosa, }\end{array}$ & $\begin{array}{r}\text { Achillea mi } \\
\text { Anthr } \\
\text { Festuc } \\
\text { Lotu } \\
\text { Primu } \\
\text { Trifoliun }\end{array}$ & $\begin{array}{l}\text { efolium, Antho } \\
\text { scus sylvestris, } \\
\text { a rubra, Leont } \\
\text { corniculatus, } \\
\text { a veris, Taraxa } \\
\text { montanum, Tr } \\
\text { Veronica offic }\end{array}$ & $\begin{array}{l}\text { im odoratum, } \\
\text { n carvi, } \\
\text { ispidus, } \\
\text { vialis, } \\
\text { icinale, } \\
\text { pratense, }\end{array}$ \\
\hline $\begin{array}{l}\text { Abundance of } \\
\text { functional groups } \\
(\%, \text { mean } \pm \text { SD })\end{array}$ & $\begin{array}{r}\text { graminoids } \\
14.2 \pm 5.5\end{array}$ & $\begin{array}{r}\text { forbs } \\
67.8 \pm 10.2\end{array}$ & $\begin{array}{r}\text { legumes } \\
14.1 \pm 9.0\end{array}$ & $\begin{array}{l}\text { graminoids } \\
49.2 \pm 25.1\end{array}$ & $\begin{array}{r}\text { forbs } \\
28.3 \pm 20.1\end{array}$ & $\begin{array}{r}\text { legumes } \\
18.8 \pm 17.9\end{array}$ \\
\hline
\end{tabular}

jected to contrasting levels of water availability (Table 1). Sheltered from natural precipitation, soil water content was manipulated by applying two distinct irrigation regimes: one providing water at regular intervals and another exposing the corresponding experimental units to extended periods of drought. Changing the atmospheric demand for water vapor driven by the natural variability in air temperature and humidity coupled to the manipulated water availability in the soil allowed us to investigate and reveal vegetation-specific conductance properties and water utilization patterns. For this study we hypothesize that the vegetation adapted to local, humid conditions and characterized by high biomass has a water-spending strategy; i.e., it will hardly reduce transpiration with decreasing soil water availability until close to the wilting point. By contrast, the water-saving strategy of the drought-adapted vegetation implies strict regulation and consequently a continuous decrease in transpiration with decreasing plant-available water. As a consequence the local 
vegetation produces more biomass in moderately dry conditions but risks hydraulic failure in very dry conditions, while the drought-adapted vegetation reduces biomass production and water use earlier and is therefore better equipped to survive severe drought.

\section{Material and methods}

\subsection{Characteristics of the experimental field site and lysimeter installation}

The study site of the experiment was established during early summer 2014 in the Long-Term Ecological Research (LTER) Austria site "Stubai" (valley bottom meadow), Neustift im Stubaital (Austria). The site for the garden experiment was located at the valley floor at $972 \mathrm{~m}$ a.s.l. (WGS84: $47.115833 \mathrm{~N}, 11.320556 \mathrm{E}$ ) in a meadow used for hay production.

For this experiment six plots of $3.5 \mathrm{~m} \times 3.5 \mathrm{~m}$ were established. Traversing the corresponding area, each plot was defined by installing half-cylindrical metal frames. In the center of each plot, these frames, which provide the base for rain shelters, reached a height of approx. $2.5 \mathrm{~m}$. In each corner at the outer plot margin, four irrigation sprinklers pointing towards the center of the plot were set up. The irrigation system described in detail by Newesely et al. (2015) was used to simulate precipitation during periods of experimental manipulation of water provision to the system.

In the center of each plot, two small-scale lysimeters with $0.3 \mathrm{~m}$ diameter and $0.3 \mathrm{~m}$ depth were installed in collaboration with, and supervised by, the employees of the manufacturer (Smart-Field-Lysimeter, UMS/Meter Group Munich, Germany). Every lysimeter was filled with a soil-vegetation monolith by cutting the hollow cylindrical lysimeter blank into an undisturbed patch of the corresponding ecosystem. This compression-free procedure allowed the original and unaffected stratification of the soil to remain in place and made it possible to conserve the natural composition of pore spaces within the monolith. The filled lysimeter blanks were subsequently excavated and cut horizontally at a depth of $0.3 \mathrm{~m}$. With $90 \%$ of root biomass distributed above $0.2 \mathrm{~m}$ in both investigated vegetation types, a lysimeter depth of $0.3 \mathrm{~m}$ was assumed to be sufficient. The bottom of the lysimeter was closed with a tension controlled hydraulic boundary connected to a bidirectional pumping system to regulate water flow into and out of the lysimeter. After inserting soil moisture, temperature (EC-5 Small Soil Moisture Sensor, Decagon Devices, USA) and matrix potential probes (MPS-2, Decagon Devices, USA) at 0.05, 0.15 and $0.25 \mathrm{~m}$ depth into the lysimeter monolith, each system was placed on a weighing platform (accuracy of $0.005 \mathrm{~kg}$, PL-50, UMS/Meter Group Munich, Germany). Two of these lysimeter units were installed in the center of every experimental plot within a two-by-two squared grid of $1.2 \mathrm{~m}$ edge length with their relative position to each other assigned randomly.

The two monoliths in every plot were excavated from different types of vegetation: one containing a mesocosm of the meadow surrounding the experimental field site $(\mathrm{S}$, Table 1) and another one which was excavated and transplanted from a meadow in Matsch/Mazia with contrasting environmental and biotic properties to those of the study site (M; Table 1). The Stubai grassland is classified as Poo trivialis Alopecuretum pratensis with a community of low complexity: abundant Poaceae accompanied by some herb species (Wohlfahrt et al., 2008). The meadow is actively managed, cut two to three times each year, and fertilized with cow manure in spring and autumn (approximately $0.35 \mathrm{~kg}$ dry matter per square meter; Table 1). The local climate is dominated by high total precipitation values, especially in the summer. The vegetation of second origin (Matsch/Mazia) is characterized by the traditional, more extensive use of the corresponding system. The Matsch Valley has a dry inner-Alpine climate with a mean precipitation of $527 \mathrm{~mm}$ per year and a mean temperature of $6.6^{\circ} \mathrm{C}$ (Hydrographical Department of the Autonomous Province of Bozen-South Tyrol). The vegetation is a dry hay meadow (Ranunculo bulbosi - Arrhenatherum, Ellmauer) on loam to sandy loam. The site is fertilized with cow dung and cut two times each year. The excavation location of the replicate lysimeters was optimized according to the presence of representative and joint species in the respective vegetation patches. After installing the local and transplanted lysimeter mesocosms during early summer 2014 in the experimental plots, the vegetation surrounding the lysimeters was allowed to recover until spring 2015 from disturbances caused by necessary soil works required to wire the fully automated measuring system. This extensive recovery period of more than 8 months including the winter season and the initial growth phase until the first harvest in the actual measuring year should provide a sufficient acclimatization and regeneration of both vegetation and soil in the lysimeters and prevent a bias between vegetation types.

At the field site, all experimental plots and the vegetation in the lysimeters was managed (cut, fertilized) concurrently with the land-use scheme of the surrounding meadow. The experimental period started in the last third of June 2015 during the regrowth interval after the first cut at the beginning of June. With the beginning of the experiment on 10 June 2015, rain shelters were closed using a UV permeable transparent polythene film (Lumisol Clear AF, 88-92\% light transmittance). Air temperature (on average $0.26 \mathrm{~K}$ higher in the shelter) and humidity $(+0.11 \%)$ were hardly affected by the shelters, while radiation was reduced by $25 \%$ and wind speed by $50 \%$ even though shelters were left open on the sides facing the main wind direction and closed down to just $0.5 \mathrm{~m}$ above the soil level on the lateral sides to minimize shielding of the wind. Concurrently with the closing of the rain shelters (10 June), precipitation was provided from the irrigation sprinklers mimicking average rain fall amounts 
(a)

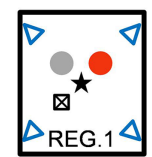

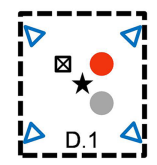
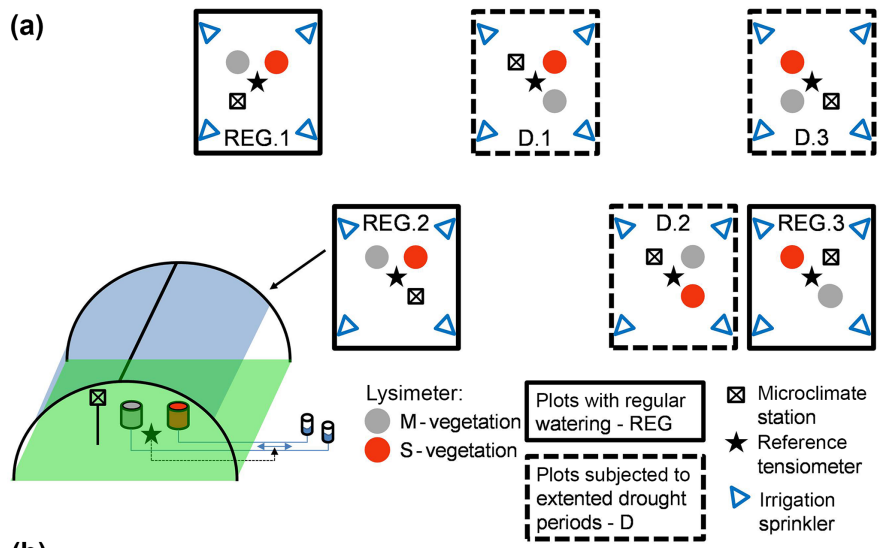

(b)

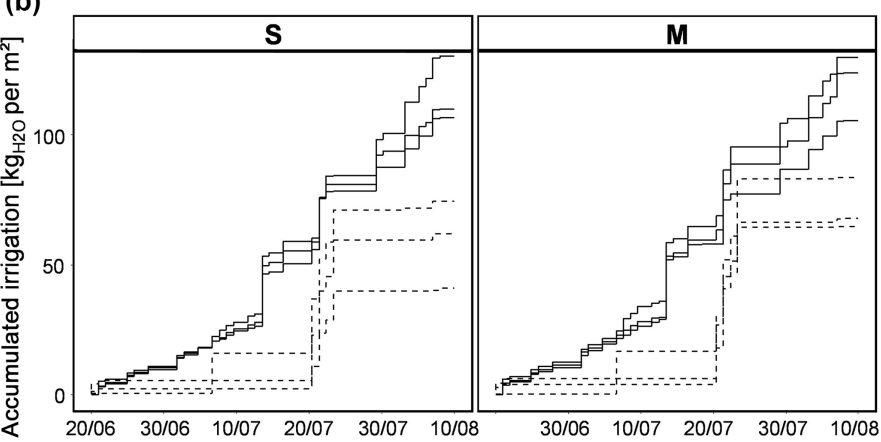

Figure 1. (a) Schematic overview of the experimental design and plot setup; (b) manipulation of water availability for individual lysimeters of the two vegetation types (Stubai (S) and Matsch/Mazia (M)) by contrasting irrigation schemes - one providing water on a regular basis (REG, solid lines), one with extended drought periods (D, dashed lines).

and intensities for the 30-year period between 1970 through 2000. Over a period of 52 days (20 June-10 August) the plots of the experiment were subjected to control watering within the two different irrigation schemes (Fig. 1), one providing water on a regular basis (REG) and one with extended drought periods (D). However, due to technical problems the watering scheme stayed below the intended amounts for approximately the first half of the experimental period making manual compensation occasionally necessary (starting on 15 July). Automated irrigation was programed to occur around midnight in order to avoid immediate transpiration from the surface and to allow the provided water to penetrate into the soil compartment. Manual adjustments and checks on the precipitation simulator were usually performed during daytime. The lysimeter mesocosms in the treatments with regular watering (REG) received approx. $117 \mathrm{~kg}_{\mathrm{H}_{2} \mathrm{O}} \mathrm{m}^{-2}$; those in the treatments with extended drought periods received an average of $65 \mathrm{~kg}_{\mathrm{H}_{2} \mathrm{O}} \mathrm{m}^{-2}$ throughout the duration of the experiment and according to the scheme presented in Fig. 1.

\subsection{Automated measurements}

In the center of each of the six plots a microclimate station measuring air temperature and relative humidity (height: $1 \mathrm{~m}$;
U23-002 HOBO $^{\circledR}$ External Temperature/Relative Humidity Data Logger, Onset Computer Corporation, USA), solar radiation (height: $1 \mathrm{~m}$; S-LIB-M003, Solar Radiation Sensor, Onset Computer Corporation, USA), wind speed (height: $1 \mathrm{~m}$; DAVIS ${ }^{\circledR}$ Standard Anemometer 7911, Davis Instruments, USA), and soil water content 0.05 and $0.2 \mathrm{~m}$ below the ground (S-SMA-M005, Soil Moisture Smart Sensor $0.2 \mathrm{~m} \mathrm{ECH} 2 \mathrm{O}^{\circledR}$ probes, Decagon, USA) was installed. The corresponding measurements were logged for every $10 \mathrm{~min}$ interval (HOBO Microstation ${ }^{\circledR}$ Data Logger; Onset Computer Corporation, USA).

For each of the lysimeter, weight data were recorded every minute; data received from matric potential, soil temperature and water content sensors (each in $0.05,0.15$ and $0.25 \mathrm{~m} \mathrm{depth}$ ) were measured at $10 \mathrm{~min}$ intervals. The hydraulic boundary at the bottom of each lysimeter was connected to a reservoir of drainage water, with the corresponding container also being placed on a balance. A bidirectional pumping system allowed the adjustment of the water content at the lower boundary of the lysimeter by transferring water either from the drainage container into the lysimeter or vice versa. This implementation allowed us to adjust the water levels at the bottom of the lysimeter according to a reference matric potential measured at the same depth in the natural unaffected soil column of the respective experimental plots. 


\subsection{Manual measurements of biomass development}

Variability in water flux from vegetation canopies to the atmosphere has two components: (a) the variation in standing biomass and (b) the water vapor release activity per unit biomass. Therefore, decomposing and addressing these two factors independently is advisable, especially when functionally different plant communities with differing biomasses are being compared. However, nondestructive biomass estimation of complex stands in the field can be challenging with respect to desired accuracy. In order to generate robust estimates different methodologies were combined in the current experiment. Measurements of maximum and average canopy height (Machado et al., 2002) were supplemented with a pinpoint procedure (Jonasson, 1988) and measurements of projected area (Lati et al., 2013) for biomass estimation in the lysimeters. For measuring pin contacts, a thin metal rod was lowered down to the lysimeter through a plate placed above. Pin measurements were replicated in 7 (out of 21) randomly assigned positions for each lysimeter and point in time. Pin contacts were referenced within three height classes $(0-20,20-40,40+\mathrm{cm}$ above the ground) and by functional group identity of the plants. For the determination of projected area of the lysimeter canopies the methodology proposed by Tackenberg (2007) was adapted. Digital images of the lysimeter stands in front of a white half-cylindrical background were scaled according to a size standard in each picture and converted to a black and white color scheme before black pixels were enumerated. On average, the biomass of the lysimeters was estimated for every third day throughout the period of the experiment. The different methods for nondestructive biomass estimation were calibrated against weighted biomass at the harvests prior and subsequent to the experiment (10 June and 10 August). Based on these calibrations the biomass development in the lysimeters was predicted throughout the experimental period.

\subsection{Data processing and statistics}

To calculate the water mass fluxes at the soil-vegetationatmosphere interface of the upper lysimeter boundary, weight differentials of the drainage reservoir and the lysimeters were summarized and subsequently cleared for spikes and signals of implausible strength (Schrader et al., 2013). The latter was necessary because the sensitive weighing elements are susceptible to environmental noise or accidental interference by other experimental proceedings (e.g., biomass estimation), while providing a high accuracy and temporal resolution. The combined weight signal was separated into irrigation-induced weight gain of the lysimeter units and weight loss caused by evapotranspiration from the upper lysimeter boundary. Subsequently, daily totals were calculated for both mass differentials.

A soil-specific calibration of the MPS-2 sensors is a necessary prerequisite to achieve the highest degree of abso- lute accuracy in soil water content (SWC) measurements. A substrate moisture retention curve ( $\mathrm{pF}$ vs. volumetric water content) and the hydraulic conductivity as a function of $\mathrm{pF}(\log 10$ of the matric potential) were determined for both types of soil-vegetation monoliths (M, S). The soil hydraulic parameters were determined in the laboratory, using the method of Schindler (1980) with the HYPROP system, a fully automated measuring and evaluation system to determine the hydraulic properties of soil samples (UMS/Meter Group Munich, Germany). Using the soil-specific moisture retention curve, absolute SWC was corrected based on soil matrix potential data. To summarize the time course of water availability in the soil of each lysimeter unit, the average values of SWC of both layers between $0.05-0.15$ and 0.15 $0.25 \mathrm{~m}$ were integrated and summarized on a daily basis.

The evaporative demand of the atmosphere is expressed by the reference crop evapotranspiration $\left(\mathrm{ET}_{0}\right)$. It represents the evapotranspiration from a standardized vegetated surface and was calculated in this study according to the FAO PenmanMonteith standard method (Allen et al., 1998). $\mathrm{ET}_{0}$ integrates the most important atmospheric components (solar radiation, temperature, vapour-pressure deficit (VPD) and wind velocity) defining the atmospheric water demand. Daily averages were used as a summed up explanatory parameter to capture the atmospheric draw of water vapor from the lysimeter vegetation for further analysis.

Nondestructive estimates of the standing biomass in the lysimeters were calibrated at the harvests before and after the experimental period. Nine different regression models were generated for the different estimation techniques individually and in combinations. Based on the prediction of these models, biomass was estimated for every measurement (total of 16) during the experiment. The biomass development in the different lysimeters followed a nonlinear trajectory. To generate a consensus time course describing the growth progression in every lysimeter, a general additive mixed model smoother was fitted for each unit (GAMM function in the mgcv package, R Development Core Team, 2015 ) with the different prediction methodologies defining random (observer) effects. The flexibility of the time course defined by these smoothers was constrained by allowing a maximum of five knots for these smoothers. Granting an approximate average of three measurement points per knot (16 to 5), successive sampling points were capable of changing the trend of biomass progression while implausible fluctuation was prevented. Based on these models, standing biomass was predicted on a dry-weight basis for every lysimeter entity and each day of the experiment.

For the evaluation of evapotranspiration responses mixedeffects models were fitted using the nlme package (Pinheiro et al., 2017). All these models included the identity of the different vegetation types (categorical) in full factorial combination with additional covariates defining the fixed part of the model as detailed below. To reveal the drivers of variation in daily ET rates and separate the effects of variation 
Table 2. Parameter and parameter interactions affecting the ET0SWC landscape of ET. Significant $p$ values are in bold.

\begin{tabular}{lrr}
\hline Parameter & $F$ value & $p$ value \\
\hline $\mathrm{ET}_{0}$ & 341.31 & $<\mathbf{0 . 0 0 1}$ \\
$\mathrm{SWC}$ & 28.09 & $<\mathbf{0 . 0 0 1}$ \\
Vegetation type & 2.81 & 0.154 \\
$\mathrm{ET}_{0} \times \mathrm{SWC}$ & 37.20 & $<\mathbf{0 . 0 0 1}$ \\
$\mathrm{ET}_{0} \times$ vegetation type & 1.24 & 0.265 \\
$\mathrm{SWC} \times$ vegetation type & 2.74 & 0.098 \\
$\mathrm{ET}_{0} \times \mathrm{SWC} \times$ vegetation type & 7.08 & $\mathbf{0 . 0 0 8}$ \\
\hline
\end{tabular}

in biomass (DW - dry weight) and evapotranspiration rates per unit biomass (ET/DW) among the different monoliths, a $\log -\log$-scaling method was applied according to the formula $\mathrm{ET}=\mathrm{ET} / \mathrm{DW} \times \mathrm{DW}$ based on the methodology provided by Renton and Poorter (2011). This procedure allows decomposing the importance of different factors of sources in the variation in a synergistically (multiplicative) defined trait and is not meant to establish a statistical relationship between independent parameters. For summarizing the time courses of SWC and $\mathrm{ET}_{0}$, the day of the experiment and the two irrigation schemes were considered as additional categorical variates. For modeling the response surface of ET along the two dimensions of $\mathrm{ET}_{0}$ and SWC, the latter two and all possible interactions with vegetation type were defined as continuous covariates for the fixed part of the model. However, all models included a random intercept for the experimental plot in which the data were collected. Nested within the random effect for the plot, the lysimeter identity was included as another random effect to fully represent the dependence structure in the hierarchical design of the experiment. Where they were found to significantly improve the model fit, lysimeter-specific responses to continuous covariates in the fixed part were included as random slopes (see Table 2). Further, to account for autocorrelative errors according to the time-series origin of the data, a continuous autocorrelation structure (corCAR1 in nlme package) was defined by the day of the experiment. All statistical analysis presented here was performed using the $\mathrm{R}$ statistical programming language ( $\mathrm{R}$ Development Core Team, 2015).

\subsection{Experimental limitations of the study}

Drought scenarios are usually generated by rainout shelters using a UV-permeable, transparent film for roofing. If compared to unroofed controls, temperature differences and the attenuation of photosynthetically active radiation reducing total productivity should be considered as artifacts of sheltering (Vogel et al., 2013). However, if both treatments are sheltered, differential irrigation only leads to varying water availabilities over time. The beginning of the present experiment was marked by the establishment of the rainout shelters and the omission of irrigation in the treatments with extended drought periods (D). From this point, it took approximately 2 weeks for the SWC of both irrigation schemes to diverge significantly in M-type mesocosms and even longer for the $S$ type. Therefore, regular irrigation and its omission can, counterintuitively, only be an indicator of contrasting water availability. The establishment of drought conditions in the strict sense of a depleted soil water reservoir is realized by the interaction of pretreatment SWC, standing biomass and atmospheric effects. Variations in vegetation water status have to be defined in the context of water availability (supply) and physiology, phenology and the leaf-to-air evaporative gradient (Gilbert and Medina, 2016). The beginning of the experiment was characterized by a combination of days with consistently high averages of $\mathrm{ET}_{0}$ and high $\mathrm{SWC}$ in all mesocosms. This combination led to high ET and a decrease in SWC for all experimental units. Due to the parallel decline in SWC irrespective of the watering regime applied, the water availability differentiation among the treatments was delayed. For such reasons, it has been argued to define variations in water availability not purely on the basis of contrasting regimes of water input (i.e., irrigated vs. non-irrigated) if these are not causing systematic variations in soil moisture (Kramer, 1983). Defining water supply based on the continuous range of SWC rather than discrete irrigation treatments considers soil-type-specific characteristics of matric potential and hydraulic conductivity. Also, practical problems with realizing discrete treatments of water availability in the field (i.e., precipitation entry to sheltered plots due to heavy winds and spatiotemporal variation in the effectiveness of automated irrigation) will be migrated by referencing ecosystem responses to gradients of water supply. Defining vegetation responses along continuous ranges of environmental factors will further yield stronger information about the response surface of the system and improves model building and testing (Beier et al., 2012).

\section{Results}

The average air temperature during the course of the experiment was $17.5^{\circ} \mathrm{C}\left( \pm 3.1^{\circ} \mathrm{C}\right.$ - standard deviation). Among the different plots, no systematic variation in temperature, relative humidity or solar radiation was measured by the microclimate stations underneath the shelters. Summarizing the different atmospheric components, defining rates of ET, $\mathrm{ET}_{0}$ was calculated. During the duration of experiment the average daily $\mathrm{ET}_{0}$ was $3.26 \mathrm{~kg}_{\mathrm{H}_{2} \mathrm{O}} \mathrm{m}^{-2} \mathrm{~d}^{-1}( \pm 1.95 \mathrm{SD})$ with a minimum at 0.75 and a maximum of $6.4 \mathrm{~kg}_{\mathrm{H}_{2} \mathrm{O} \mathrm{m}} \mathrm{m}^{-2} \mathrm{~d}^{-1}$. However, since $\mathrm{ET}_{0}$ is subject to short-term natural variation in the underlying environmental parameters, fluctuations between consecutive days were found to be very pronounced and no temporal trend was revealed over the period of the experiment (Fig. 2).

During the time of the experiment, the two contrasting irrigation schemes led to distinct SWC dynamics within the 

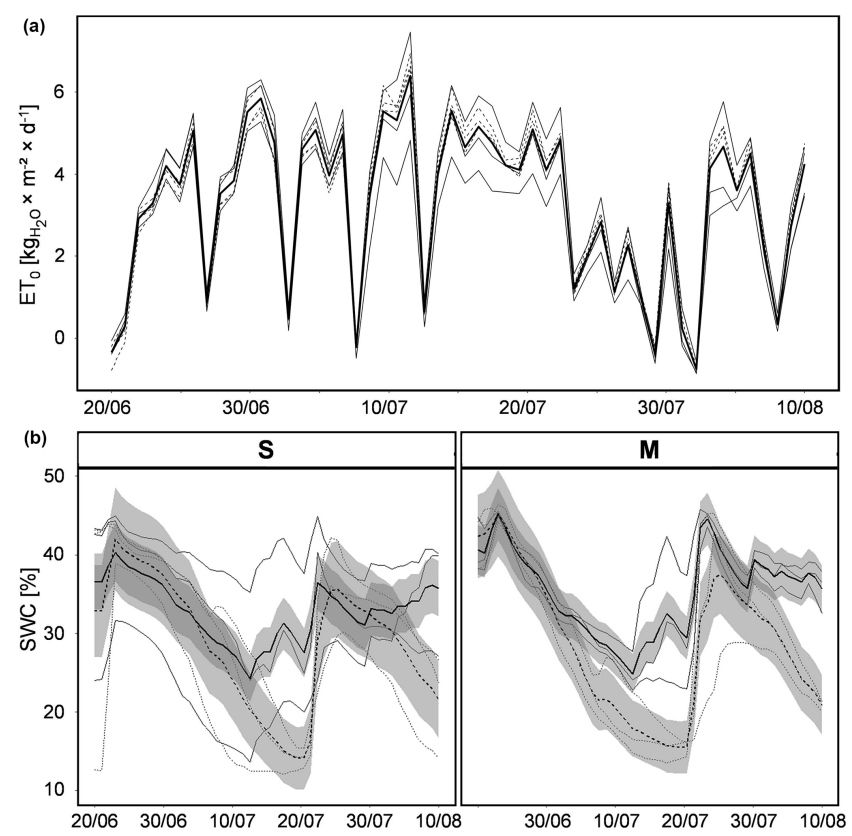

Figure 2. Atmospheric demand $\left(\mathrm{ET}_{0}\right)$ and $\mathrm{SWC}$ as drivers of ET: (a) dynamics of daily average $\mathrm{ET}_{0}$ over the course of the experiment (bold line: all-plot average; thin lines: individual plots); (b) dynamics of daily average SWC for two vegetation types (S and M; see Table 1) in contrasting irrigation schemes (REG - solid lines; D - dashed lines; bold lines: treatment average; shaded area: standard deviation; thin lines: individual plots); S: Stubai; M: Matsch/Mazia.

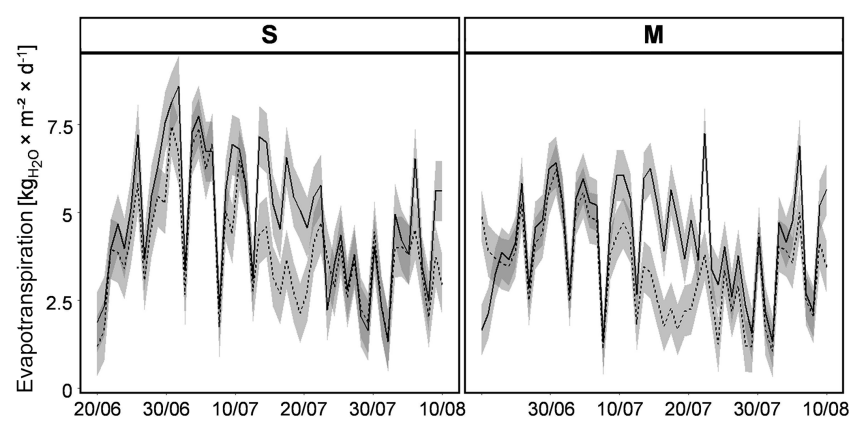

Figure 3. Dynamics of daily average ET over the course of the experiment for two different vegetation types ( $\mathrm{S}$ and $\mathrm{M}$; Table 1) subjected to contrasting irrigation regimes (REG - solid lines; D - dashed lines; shaded area - standard deviation); S: Stubai; M: Matsch/Mazia.

respective mesocosms (Fig. 2). Since SWC in all lysimeters was high at the beginning of the experiment, the value initially decreased in all plots irrespective of treatment indicating that the water distributed on plots with regular irrigation did not fully compensate for the loss of water by ET of the corresponding plant communities. The first clear effects of different irrigation became apparent in the lysimeters with the $\mathrm{M}$ type of vegetation only after approximately 2 weeks of drought. In the lysimeters with the $\mathrm{S}$ type of vegetation,

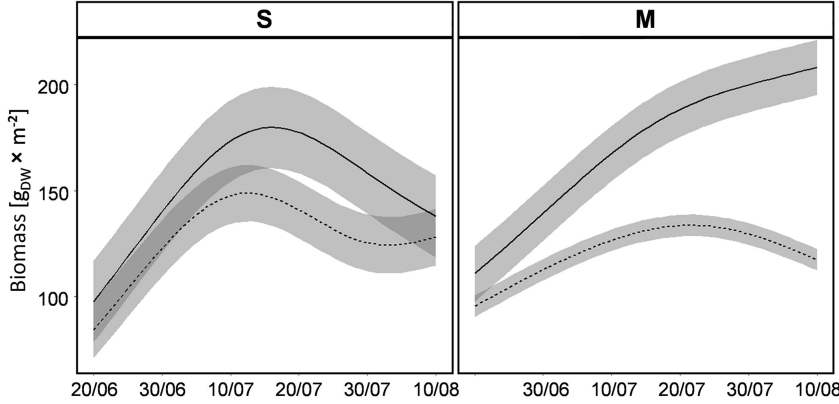

Figure 4. Predictions of biomass development for the two vegetation types (S: Stubai; M: Matsch/Mazia; Table 1) subjected to contrasting irrigation regimes (REG - solid lines; D - dashed lines; shaded area - standard deviation) throughout the duration of the experiment based on nondestructive measurements. Measured values used for these predictions are shown in Supplement Fig. S1.

the variability in SWC was far stronger; a distinct difference between watering schemes could be observed there only after the start of additional manual watering. After approximately 1 month, SWC in both vegetation types revealed clear effects of the contrasting irrigation strategies. At that time, SWC of both treatments was restored to similar values observed during the initial stages of the experimental period in order to avoid distress in the drier mesocosms. Rates of daily ET from the lysimeters varied very strongly through the period of the experiment and did not reveal a general temporal trend (Fig. 3). As the canopy height and biomass of both vegetation types was clearly higher than the reference vegetation assumed for $\mathrm{ET}_{0}$, the average evapotranspirative water loss for the lysimeter unit during the duration of the experiment also surpassed $\mathrm{ET}_{0}$ with $4.9 \mathrm{~kg}_{\mathrm{H}_{2} 0} \mathrm{~m}^{-2} \mathrm{~d}^{-1}$. Subject to the atmospheric water vapor pressure deficit the recorded fluxes were characterized by a similar unsteadiness, as the variability in the underlying environmental parameters would suggest. During the first third of the experiment, ET of the S-type lysimeters was on average higher than that of the M type; afterwards no clear difference between vegetation types could be detected. A clear difference in ET between contrasting irrigation regimes was only found during periods of a strong divergence of SWC among the two treatments (approx. 15 to 25 July); during the rest of the experimental period, ET in the drought regime was only slightly lower than in the regular one.

The prediction of biomass development combined from the different noninvasive estimation methods suggested distinct growth trajectories for the two vegetation types in interaction with the two irrigation regimes. The mesocosms with plant communities belonging to the local $S$ type revealed a larger biomass increment during early stages of the experiment irrespective of the applied irrigation regime (Fig. 4). However, with increasing duration of the experiment, growth dynamics started diverging in treatments with contrasting 


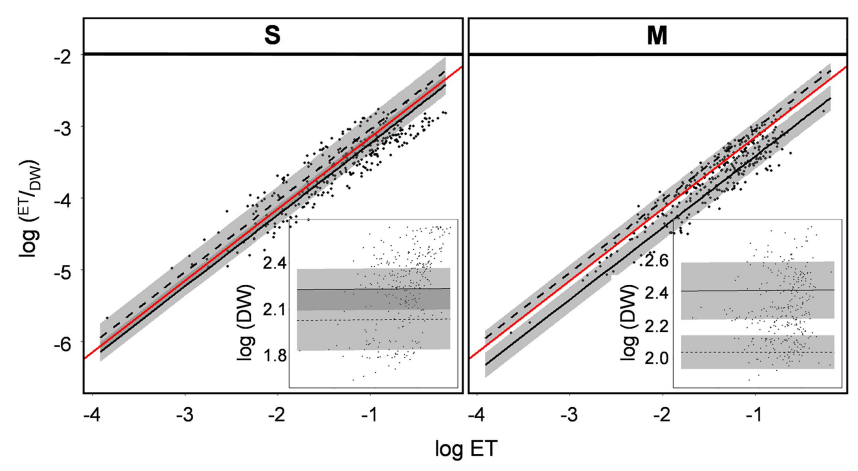

Figure 5. Log-log scaling for the two factors defining variability in ET: ET/DW and DW for the two different vegetation types (S and $\mathrm{M}$; Table 1) subjected to contrasting irrigation regimes (REG solid lines; D - dashed lines; shaded area - standard deviation); red line indicates a reference function with the slope of $1 . X$-axes of the subplots have the same limits and units as the corresponding main plots.

water provision, with biomass differences peaking at the midpoint of the experimental period. After that peak, the prediction of dry weight suggested a decline in standing biomass for both water regimes in the $\mathrm{S}$ communities. Towards the end of the experiment, biomasses of communities in the different water treatments converged to similar values. This pattern of vegetation development indicates that the early irrigation rates of the REG treatment were indeed too low and the manual compensation came too late for a regular development of the vegetation. Thus, the S-type lysimeters subjected to the REG treatment also suffered a drought related early peak of biomass and subsequent senescence with just a short delay to the $\mathrm{D}$ treatment. A different pattern of biomass development was detected for the transplanted mesocosms (M). From the beginning of the experiment growth processes of the different irrigation treatments yielded distinct trajectories. In the treatment experiencing regular water provision, the biomass gain per unit time was stronger than in the mesocosms being subjected to drought. That pattern was consistent throughout the experiment, with a strictly monotonic increase in standing biomass in the $\mathrm{M}$ communities of wellwatered plots. In contrast, the vegetation of the $M$ type in the plots with restricted watering growth started stagnating during the second half of the experimental period. Unlike the $\mathrm{S}$ type, at the end of the investigation period, biomasses in the M-type communities were clearly distinct according to the different watering regimes, with the standing mass in the regularly watered plots approximating double the amount compared to the treatment with restricted water provision.

Variability in ET is subject to variation in evapotranspiration rates per unit biomass (ET/DW) and the variation in the standing biomass. Hence, when comparing rates of ET, differentiating both underlying components will provide deeper insights on how the vegetation interface of different plant communities mediate the water flux from the soil. A strong positive correlation of total daily ET and ET/DW was found (Fig. 5). The log-log scaling of ET/DW with ET revealed a slope of 0.998 , arguing that variation in ET rates measured during the course of this experiment is almost exclusively defined by the variation in ET rates per unit biomass $(100 \%=1)$. This relationship was independent of vegetation type and irrigation scheme. However, variations in biomass did not have an effect on the variability in total ET rates (Fig. 5).

After revealing ET/DW as the most important driver in defining variation in the rates of total ET from the lysimeter mesocosms, the effect of combined variation in $\mathrm{ET}_{0}$ and $\mathrm{SWC}$ on rates of ET per unit biomass was modeled in dependence on the vegetation type $\left(\mathrm{ET} / \mathrm{DW}=f\left(\mathrm{ET}_{0} \times \mathrm{SWC} \times\right.\right.$ vegetation type $\left.)\right)$. On the entire field site, on average the daily sums of $\mathrm{ET}_{0}$ ranged from -0.75 to a maximum of $6.4 \mathrm{~kg}_{\mathrm{H}_{2} \mathrm{O}} \mathrm{m}^{-2} \mathrm{~d}^{-1}$, while within the individual plots, daily average values ranged from -0.86 to 7.2 of $6.4 \mathrm{~kg}_{\mathrm{H}_{2} \mathrm{O}} \mathrm{m}^{-2}$. The averaged SWC realized during the duration of the experiment covered a range from approximately 12 to $47 \%$ (Fig. 5). Both $\mathrm{ET}_{0}$ and SWC had a highly significant and positive effect on achieved rates of ET/DW (Fig. 6, Table 2). However, as implied by a significant synergistic interaction of $\mathrm{ET}_{0}$ and SWC, rates of ET/DW increased more strongly than the individual gradients of either would imply if SWC and $\mathrm{ET}_{0}$ increased concurrently (Fig. 6). With increasing $\mathrm{ET}_{0}$ the response of ET/DW was stronger, the higher SWC was. However, there was a significant difference in how both vegetation types responded within the landscape of environmental drivers defining ET/DW (Table 2). The local (S) vegetation had higher rates of ET/DW - when both $\mathrm{ET}_{0}$ and SWC were low - than the transplanted vegetation type (M), suggesting a higher base rate of ET/DW. On the low end of investigated SWC, the M vegetation had a stronger response to $\mathrm{ET}_{0}$ than the local $\mathrm{S}$ vegetation. Despite that stronger response of the transplanted vegetation (M) along the $\mathrm{ET}_{0}$ gradient at low SWC, the maximum rates of ET/DW converted to similar values due to the higher base flux at low $\mathrm{ET}_{0} /$ low $\mathrm{SWC}$ in the $\mathrm{S}$ vegetation. In turn, under conditions of high soil water availability, the $\mathrm{ET}_{0}$ response of the $\mathrm{S}$ type was much more pronounced than in the $\mathrm{M}$ type. A similar pattern was found comparing the SWC response of both vegetation types for the range of different $\mathrm{ET}_{0}$ values realized during the experiment. At low $\mathrm{ET}_{0}$ the M-type vegetation responded more strongly to variations in SWC, while there was almost no response in the $\mathrm{S}$ type. However, at high $\mathrm{ET}_{0}$ the response of the S type to increasing SWC was again much more pronounced than in lysimeters with the M type. Because of the higher rates of ET/DW at low $\mathrm{ET}_{0} / \mathrm{SWC}$ and the overall increased response potential of the S-type vegetation, the ET/DW values achieved in the M communities stayed below those found in the local vegetation for almost the entire range of combinations between $\mathrm{ET}_{0}$ and $\mathrm{SWC}$ investigated in this experiment. 
(a)

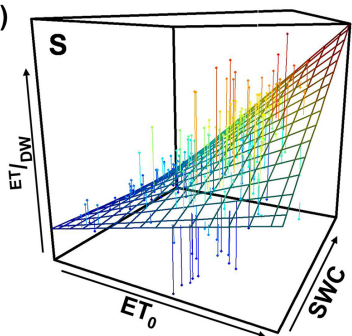

(b)

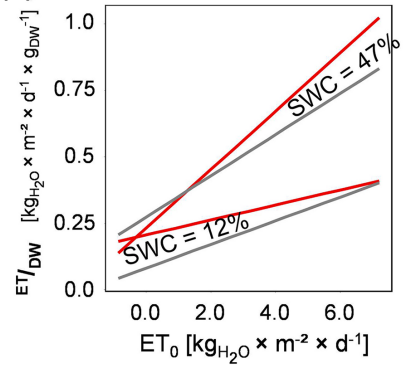

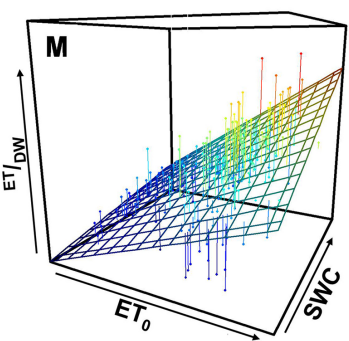
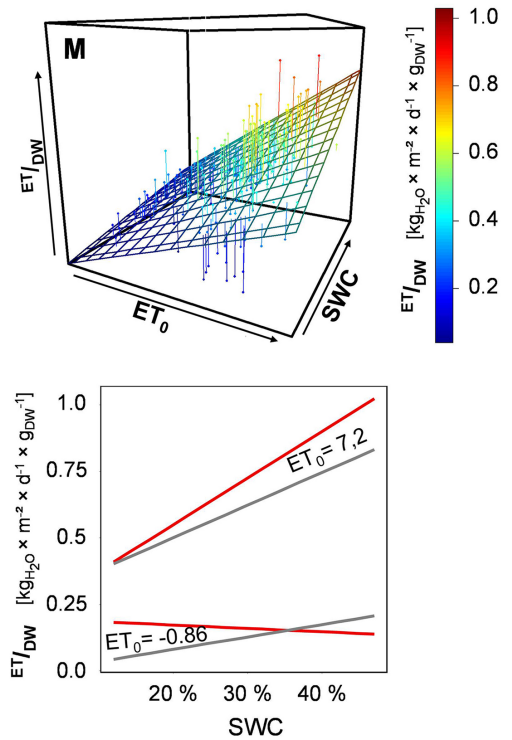

Figure 6. (a) Three-dimensional plots: response surface of ET/DW along the two-dimensional variation in $\mathrm{ET}_{0}$ and $\mathrm{SWC}_{\text {for the two different }}$ vegetation types (S: Stubai; M: Matsch/Mazia; Table 1); (b) projections of ET/DW response along $\mathrm{ET}_{0}$ and $\mathrm{SWC}_{\text {at }}$ maximum/minimum value of the other (red: $\mathrm{S}$ communities; gray: M communities).

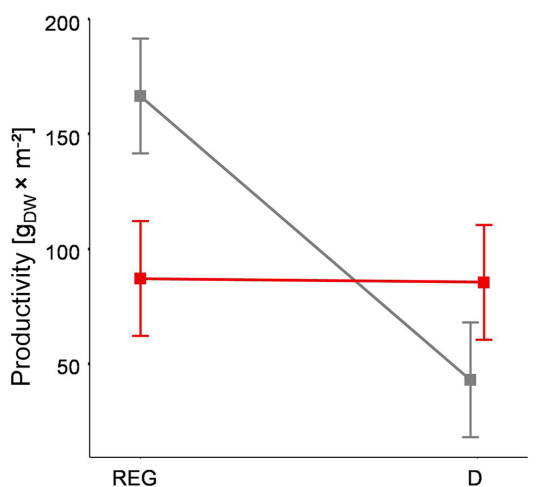

(a) Irrigation regime

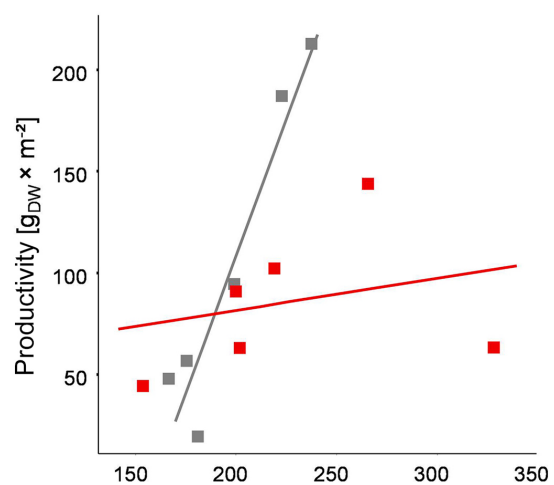

(b) Accumulated ET $\left[\mathrm{kg}_{\mathrm{H} 2 \mathrm{O}} \times \mathrm{m}^{-2}\right]$

Figure 7. (a) Productivity of two vegetation types ( \pm standard error; Stubai - red; Matsch/Mazia - gray; Table 1) subjected to contrasting irrigation schemes (Fig. 1); (b) - dry matter productivity of two vegetation types (see above) as function of accumulated evapotranspiration over the experimental duration.

Comparing the productivity of the two vegetation types among the two irrigation treatments revealed a contrasting response for the DW productivity (Fig. 7a). For the local S type, the biomass gain over the experimental period did not show a strong dependence on the applied watering regime. Due to the insufficient irrigation mentioned before, the productivity of the S type stayed well below what would be expected for the vegetation outside the experimental site in both treatments. For the M communities, however, productivity was on average more than 2-fold higher in the plots experiencing regular water provision compared to those exposed to extended periods of drought.
Integrated over the entire experimental period, the biomass productivity per unit water usage was significantly higher for the transplanted mesocosms M (Fig. 7, right panel). The data suggested a productivity increase in $2.6 \mathrm{~g}_{\mathrm{DW} \mathrm{kg}}{ }^{-1}$ of water for the $\mathrm{M}$ vegetation. In contrast, for the S-type mesocosms the average increase in productivity per $1 \mathrm{~kg}$ of evapotranspiration was approximately only $0.16 \mathrm{~g}_{\mathrm{DW} \mathrm{kg}} \mathrm{kg}^{-1}$ but was strongly influenced by the highly variable productivity of the two lysimeters with the highest accumulated ET. (Neglecting this one observation, productivity in the $S$ vegetation was around $0.91 \mathrm{~g}_{\mathrm{DW} \mathrm{kg}}-1$ of water.) This pattern suggests that biomass generation in the M-type vegetation is strongly dependent on ET and therefore water availability. For the S- 
type vegetation the early decrease in biomass in both treatments and the high variability in productivity at high ET made it difficult to assess an integrated trend in water use efficiency for the entire experimental period.

\section{Discussion}

It can be understood intuitively that $\mathrm{ET}_{0}$ and SWC impose independent and interacting effects on water fluxes from the soil to the atmosphere with one of either constraining the total rates of ecosystem ET (Kim and Verma, 1991; Perez et al., 2006). Beyond the effects of these abiotic drivers, the measurements of the present experiment reveal a plantcommunity-specific signal in the definition of ecosystem water exchange. The plant-community-specific configuration of the soil-plant-atmosphere interface is instinctively acknowledged if distinct vegetation types are compared. Water fluxes from the system will to some degree always scale with productivity and total biomass of the vegetation (Zeppel et al., 2014, and references therein). This relationship will drive variation in ET of contrasting biomes together with environmental parameters affecting the availability and the atmospheric demand for water.

However, results of this experiment reveal that water fluxes along cooperating gradients of $\mathrm{SWC}$ and $\mathrm{ET}_{0}$ indicated divergence in the conductance potential of the two Alpine grassland communities, which defines ecosystem water flux beyond the impact of variations in total biomass. Such differences will be important to understand and to consider if plant communities of the same type need to be evaluated with respect to their particular impact on the hydrological regulation of the ecosystem. At low SWC, lower values of ET/DW for the M-type vegetation indicate a better ability to control water loss in dry conditions event though the difference to the $\mathrm{S}$ type diminishes with increasing $\mathrm{ET}_{0}$. Conversely, under conditions of high soil water availability water fluxes from the $S$ type responded much more strongly to increases in $\mathrm{ET}_{0}$, suggesting a higher overall conductance potential. Similar implications were revealed along the gradient of soil water availability. SWC variations had almost no effect on the S-type communities when the atmospheric draw was small, while the M-type mesocosm still mediated fluxes to the atmosphere. The divergence in the response of ET between $\mathrm{S}$ and $\mathrm{M}$ communities to varying SWC suggests that, from starting at similar rates, ET of the $M$ type increased far more strongly with increasing SWC. This relationship is also supported by direct measurements of stomatal conductance. In a study by Ringler (2017) it was found that the dominant species of the $\mathrm{M}$ community increasingly close their stomata with decreasing SWC $(y=4.8721 \times \mathrm{SWC}+42.824$; $\left.R^{2}=0.333 ; p=0.031\right)$, where $y$ is the stomatal conductance $\left(\mathrm{mmol} \mathrm{m} \mathrm{m}^{-2} \mathrm{~s}^{-1}\right)$. This trend could not be observed in the species of the S community $(y=-0.8054 \times \mathrm{SWC}+210.79$; $\left.R^{2}=0.018 ; p=0.625\right)$. These differences between the two vegetation types indicate different strategies in water utilization. For the $M$ type this strategy may be summarized by overall lower ET rates than for the $\mathrm{S}$ type for most environmental scenarios included within the experimental period and a stronger control of transpiration especially at low SWC. This implies an overall conservative and watersaving strategy. For the $\mathrm{S}$ communities, in contrast, which show high water conductance potential with strongly increasing ET rates when environmental conditions become less constraining, an acquisitive strategy is suggested. With high rates even at base level, this plant community appears not to be optimized to save water and might experience drought effects earlier and probably more strongly, when water availability becomes limiting. With respect to their stomatal control, the (dominant species of the) $\mathrm{M}$ communities could also be defined as isohydric and the $\mathrm{S}$ communities as anisohydric; however, the characterization as watersaving/water-spending more comprehensively describes the water use and biomass production of the two plant canopies (see also Martínez-Vilalta and Garcia-Forner, 2017).

There might be some dampening effect of soil hydrological properties event though the slightly higher amount of plant-available water for the $S$ type might be offset by a finer texture and higher organic matter content regarding soil water storage capacity. The different pattern of SWC with an earlier distinction between the REG and D treatments after the first 2-3 weeks of the experiment are more likely caused by the lower ET of the M-type vegetation during this period. Although soil hydrological properties play a role in the plant-community-specific conductance potential of soil water to the atmosphere, differences found for the investigated two different vegetation types turned out to be not decisive in this context.

Sharing a common environment, the differences in biomass-independent conductance potential between the two Alpine grassland communities are likely to have a foundation in a contrasting physiological, functional and structural organization of the vegetation. Functional divergence in water utilization, evapotranspiration and other aspects of the hydrological regulation of ecosystems (e.g., infiltration, surface runoff) between plant communities can be manifested by the frequency distribution in the values of particular traits (Díaz et al., 2013). Canopy complexity, density and size, plant growth form composition, plant species composition and diversity of vascular structures, stomatal density, and conductance mediate plant-community-specific differences in the evapotranspiration aboveground (de Bello et al., 2010). Belowground, the structure and depth of the individual rooting systems is an important determinant for the water utilization potential of plant communities (Knapp et al., 2008). Along the variation and composition of these traits, water usage and consequently also drought resistance of contrasting plant communities is defined. The differences in the two vegetation types suggest a high exploitation potential for scarce soil water, probably facilitated by a higher priority on water 
exploitation in the soil in the $\mathrm{M}$ mesocosms and, conversely, a stronger importance of aboveground structures mediating light capture and gas exchange, leading to an increased response potential of ET for atmospheric triggers in the local S communities.

The clear vegetation response to variable water availability observed in the present experiment is not common in studies targeting Alpine grasslands (de Bello et al., 2010). Based on multi-annual measurements of evapotranspiration at 16 sites in the Austrian Alps, it was suggested, that even during years with low annual precipitation, Alpine grasslands do not experience water stress (Wieser et al., 2008). Gilgen and Buchmann (2009) could not draw any conclusions on a general drought response of grasslands in Switzerland, while acknowledging a site-specific impact, with plant communities that received less annual precipitation being more susceptible to drought stress than those at higher rainfall levels. Also arguing for a co-defined and interactive manifestation in the effects of varying water availability, a strong drought response of Alpine grassland functioning was revealed under scenarios of co-occurring heat waves (De Boeck et al., 2016). A modeling study for grassland ecosystems in the Austrian and French Alps suggested a higher vulnerability to drought for plant communities with a water-spending strategy relating to water provision of the ecosystems in general (Leitinger et al., 2015). However, it seems inappropriate to provide a general summary on the response of Alpine grasslands to variations in water availability given the small body of research.

\section{Conclusions}

Irrespective of the variability in different water availabilities within the two irrigation regimes, mesocosms subjected to regular watering (REG) had on average a higher productivity than those with irregular and, in total, less irrigation. However, significant differences between the different plant communities were found in the response to variations in the water supply (Fig. 7). Relating total productivity to the amount of evapotranspirative water release over the experimental period revealed a higher biomass gain per unit water in the M-type communities. The higher water use efficiency in the biomass production of these mesocosms together with their overall stronger water-saving strategy reinforces their optimization to scarce water supply. For the local S communities, in contrast, the low biomass differential per unit water consumption indicates a high potential to conduct water from the soil to the atmosphere and suggests that productivity of this vegetation is probably not often constrained by water availability in its natural context. Brilli et al. (2011) expect a water-spending strategy to have a cooling feedback in terms of climate warming. Hence, the optimization of future grassland management could play a crucial role by adapting species composition. Furthermore, understanding the specific hydraulic conductance potential of soil water for varying grassland ecosystems is a prerequisite to achieve a maximum agricultural yield in a future environment. However, a negative feedback for water provision services (i.e., downstream water users) must be expected. Further decisive changes remain debatable. How will "water-spending" plant communities adapt if droughts occur more frequently and possibly with higher intensities (Bahn et al., 2014; Reichstein et al., 2013)? To what extent do physiological and morphological changes in single plant species play a role or is there an immediate shift to better adapted plant species?

Data availability. All data are available upon request to the authors.

Supplement. The supplement related to this article is available online at: https://doi.org/10.5194/bg-15-1065-2018-supplement.

Competing interests. The authors declare that they have no conflict of interest.

Acknowledgements. We wish to thank Valentin Schießendoppler, Jana Schönherr and Jakob Fitzner for their help in the field and during the analysis in the lab. The funding partners that have supported this research include the project ClimAgro (Autonome Provinz Bozen - Südtirol, Abteilung Bildungsförderung, Universität und Forschung) and the Austrian Federal Ministry of Science, Research and Economy with the HRSM cooperation project KLIMAGRO. This study was conducted on the LTER site "Stubai" (LTSER platform "Tyrolean Alps") and the LTSER platform "IT25 - Val Mazia/Matschertal". Both sites belong to the national and international Long-Term Ecological Research Networks (LTER-Austria, LTER-Italy, LTER-Europe and ILTER). We thank the collaborators of the Botanical Garden of the University of Innsbruck for their support. Ulrike Tappeiner and Georg Leitinger are part of the research focus "Alpine Space - Man and Environment" at the University of Innsbruck.

Edited by: Paul Stoy

Reviewed by: three anonymous referees

\section{References}

Allen, R. G., Pereira, L. S., Raes, D., and Smith, M.: Crop evapotranspiration - Guidelines for computing crop water requirements - FAO Irrigation and drainage paper 56, FAO, Rome, Italy, 1998.

Auer, I., Böhm, R., Jurkovic, A., Lipa, W., Orlik, A., Potzmann, R., Schöner, W., Ungersböck, M., Matulla, C., Briffa, K., Jones, P., Efthymiadis, D., Brunetti, M., Nanni, T., Maugeri, M., Mercalli, L., Mestre, O., Moisselin, J.-M., Begert, M., MüllerWestermeier, G., Kveton, V., Bochnicek, O., Stastny, P., Lapin, M., Szalai, S., Szentimrey, T., Cegnar, T., Dolinar, M., GajicCapka, M., Zaninovic, K., Majstorovic, Z., and Nieplova, E.: 
HISTALP - historical instrumental climatological surface time series of the Greater Alpine Region, Int. J. Climatol., 27, 17-46, 2007.

Bahn, M., Schmitt, M., Siegwolf, R., Richter, A., and Brüggemann, N.: Does photosynthesis affect grassland soil-respired $\mathrm{CO}_{2}$ and its carbon isotope composition on a diurnal timescale?, New Phytol., 182, 451-60, 2009.

Bahn, M., Reichstein, M., Dukes, J. S., Smith, M. D., and McDowell, N. G.: Climate-biosphere interactions in a more extreme world, New Phytol., 202, 356-359, 2014.

Beier, C., Beierkuhnlein, C., Wohlgemuth, T., Penuelas, J., Emmett, B., Körner, C., de Boeck, H., Christensen, J. H., Leuzinger, S., Janssens, I. A., and Hansen, K.: Precipitation manipulation experiments - challenges and recommendations for the future, Ecol. Lett., 15, 899-911, 2012.

Beniston, M.: Mountain Climates and Climatic Change: An Overview of Processes Focusing on the European Alps, Pure Appl. Geophys., 162, 1587-1606, 2005.

Beniston, M.: Impacts of climatic change on water and associated economic activities in the Swiss Alps, J. Hydrol., 412, 291-296, 2012.

Beniston, M., Stephenson, D. B., Christensen, O. B., Ferro, C. A. T., Frei, C., Goyette, S., Halsnaes, K., Holt, T., Jylhä, K., Koffi, B., Palutikof, J., Schöll, R., Semmler, T., and Woth, K.: Future extreme events in European climate: an exploration of regional climate model projections, Climatic Change, 81, 71-95, 2007.

Bogena, H., Schulz, K., and Vereecken, H.: Towards a network of observatories in terrestrial environmental research, Adv. Geosci., 9, 109-114, 2006.

Böhm, R., Auer, I., Brunetti, M., Maugeri, M., Nanni, T., and Schöner, W.: Regional temperature variability in the European Alps: 1760-1998 from homogenized instrumental time series, Int. J. Climatol., 21, 1779-1801, 2001.

Brilli, F., Hörtnagl, L., Hammerle, A., Haslwanter, A., Hansel, A., Loreto, F., and Wohlfahrt, G.: Leaf and ecosystem response to soil water availability in mountain grasslands, Agr. Forest Meteorol., 151, 1731-1740, 2011.

Ciccarelli, N., von Hardenberg, J., Provenzale, A., Ronchi, C., Vargiu, A., and Pelosini, R.: Climate variability in north-western Italy during the second half of the 20th century, Global Planet. Change, 63, 185-195, 2008.

de Bello, F., Lavorel, S., Díaz, S., Harrington, R., Cornelissen, J. H. C., Bardgett, R. D., Berg, M. P., Cipriotti, P., Feld, C. K., Hering, D., Martins da Silva, P., Potts, S. G., Sandin, L., Sousa, J. P., Storkey, J., Wardle, D. A., and Harrison, P. A.: Towards an assessment of multiple ecosystem processes and services via functional traits, Biodiv. Conserv., 19, 2873-2893, 2010.

De Boeck, H. J., Bassin, S., Verlinden, M., Zeiter, M., and Hiltbrunner, E.: Simulated heat waves affected alpine grassland only in combination with drought, New Phytol., 209, 531-541, 2016.

Díaz, S., Purvis, A., Cornelissen, J. H. C., Mace, G. M., Donoghue, M. J., Ewers, R. M., Jordano, P., and Pearse, W. D.: Functional traits, the phylogeny of function, and ecosystem service vulnerability, Ecol. Evolut., 3, 2958-2975, 2013.

Estiarte, M., Vicca, S., Peñuelas, J., Bahn, M., Beier, C., Emmett, B. A., Fay, P. A., Hanson, P. J., Hasibeder, R., Kigel, J., Kröel-Dulay, G., Larsen, K. S., Lellei-Kovács, E., Limousin, J.-M., Ogaya, R., Ourcival, J.-M., Reinsch, S., Sala, O. E., Schmidt, I. K., Sternberg, M., Tielbörger, K., Tietema, A., and
Janssens, I. A.: Few multiyear precipitation-reduction experiments find a shift in the productivity-precipitation relationship, Glob. Change Biol., 22, 2570-2581, 2016.

Gilbert, M. E. and Medina, V.: Drought Adaptation Mechanisms Should Guide Experimental Design, Trends Plant Sci., 21, 639647, 2016.

Gilgen, A. K. and Buchmann, N.: Response of temperate grasslands at different altitudes to simulated summer drought differed but scaled with annual precipitation, Biogeosciences, 6, 2525-2539, https://doi.org/10.5194/bg-6-2525-2009, 2009.

Gobiet, A., Kotlarski, S., Beniston, M., Heinrich, G., Rajczak, J., and Stoffel, M.: 21st century climate change in the European Alps - A review, Sci. Total Environ., 493, 1138-1151, 2014.

Hasibeder, R., Fuchslueger, L., Richter, A., and Bahn, M.: Summer drought alters carbon allocation to roots and root respiration in mountain grassland, New Phytol., 205, 1117-1127, 2015.

Heimann, M. and Reichstein, M.: Terrestrial ecosystem carbon dynamics and climate feedbacks, Nature, 451, 289-292, 2008.

Ingrisch, J., Karlowsky, S., Anadon-Rosell, A., Hasibeder, R., König, A., Augusti, A., Gleixner, G., and Bahn, M.: Land Use Alters the Drought Responses of Productivity and $\mathrm{CO}_{2}$ Fluxes in Mountain Grassland, Ecosystems, https://doi.org/10.1007/s10021-017-0178-0, 2017.

IPCC: Managing the Risks of Extreme Events and Disasters to Advance Climate Change Adaptation. A Special Report of Working Groups I and II of the Intergovernmental Panel on Climate Change, Cambridge University Press, Cambridge, UK and New York, NY, USA, 2012.

IPCC: Climate Change 2013: The Physical Science Basis, Contribution of Working Group I to the Fifth Assessment Report of the Intergovernmental Panel on Climate Change, Cambridge, United Kingdom and New York, NY, USA, 1535 pp., 2013.

Jonasson, S.: Evaluation of the Point Intercept Method for the Estimation of Plant Biomass, Oikos, 52, 101-106, 1988.

Kim, J. and Verma, S. B.: Modeling canopy stomatal conductance in a temperate grassland ecosystem, Agr. Forest Meteorol., 55, 149-166, 1991.

Knapp, A. K., Beier, C., Briske, D. D., Classen, A. T., Luo, Y., Reichstein, M., Smith, M. D., Smith, S. D., Bell, J. E., Fay, P. A., Heisler, J. L., Leavitt, S. W., Sherry, R., Smith, B., and Weng, E.: Consequences of More Extreme Precipitation Regimes for Terrestrial Ecosystems, BioScience, 58, 811-821, 2008.

Kramer, P. J.: Water Relations of Plants, Academic Press, 1983.

Lati, R. N., Manevich, A., and Filin, S.: Three-dimensional imagebased modelling of linear features for plant biomass estimation, Int. J. Remote Sens., 34, 6135-6151, 2013.

Leitinger, G., Ruggenthaler, R., Hammerle, A., Lavorel, S., Schirpke, U., Clement, J.-C., Lamarque, P., Obojes, N., and Tappeiner, U.: Impact of droughts on water provision in managed alpine grasslands in two climatically different regions of the Alps, Ecohydrology, 8, 1600-1613, 2015.

Machado, S., Bynum, E. D., Archer, T. L., Lascano, R. J., Wilson, L. T., Bordovsky, J., Segarra, E., Bronson, K., Nesmith, D. M., and $\mathrm{Xu}, \mathrm{W}$.: Spatial and Temporal Variability of Corn Growth and Grain Yield This research was supported by the Texas State Legislature Initiative on Precision Agriculture for the Texas High Plains, Crop Sci., 42, 1564-1576, 2002.

Martínez-Vilalta, J. and Garcia-Forner, N.: Water potential regulation, stomatal behaviour and hydraulic transport under drought: 
deconstructing the iso/anisohydric concept, Plant Cell Environ., 40, 962-976, 2017.

Messerli, B., Viviroli, D., and Weingartner, R.: Mountains of the world: Vulnerable Water Towers for the 21st century, Ambio, 13, 29-34, 2004.

Newesely, C., Leitinger, G., Zimmerhofer, W., Kohl, B., Markart, G., Tasser, E., and Tappeiner, U.: Rain simulation in patchy landscapes: Insights from a case study in the Central Alps, Catena, 127, 1-8, 2015.

Peñuelas, J., Gordon, C., Llorens, L., Nielsen, T., Tietema, A., Beier, C., Bruna, P., Emmett, B., Estiarte, M., and Gorissen, A.: Nonintrusive Field Experiments Show Different Plant Responses to Warming and Drought Among Sites, Seasons, and Species in a North-South European Gradient, Ecosystems, 7, 598-612, 2004.

Perez, P. J., Lecina, S., Castellvi, F., Martínez-Cob, A., and Villalobos, F. J.: A simple parameterization of bulk canopy resistance from climatic variables for estimating hourly evapotranspiration, Hydrol. Process., 20, 515-532, 2006.

Peters, A., Nehls, T., Schonsky, H., and Wessolek, G.: Separating precipitation and evapotranspiration from noise - a new filter routine for high-resolution lysimeter data, Hydrol. Earth Syst. Sci., 18, 1189-1198, https://doi.org/10.5194/hess-18-1189-2014, 2014.

Pinheiro, J., Bates, D., DebRoy, S., Sarkar, D. and R Core Team: nlme: Linear and Nonlinear Mixed Effects Models, R package version 3.1-131, https://CRAN.R-project.org/package= nlme, 2017.

Poorter, H., Niklas, K. J., Reich, P. B., Oleksyn, J., Poot, P., and Mommer, L.: Biomass allocation to leaves, stems and roots: meta-analyses of interspecific variation and environmental control, New Phytol., 193, 30-50, 2012.

R Development Core Team: R: A language and environment for statistical computing, R Foundation for Statistical Computing, Vienna, Austria, 2015.

Rebetez, M. and Reinhard, M.: Monthly air temperature trends in Switzerland 1901-2000 and 1975-2004, Theor. Appl. Climatol., 91, 27-34, 2008.

Reichstein, M., Bahn, M., Ciais, P., Frank, D., Mahecha, M. D., Seneviratne, S. I., Zscheischler, J., Beer, C., Buchmann, N., Frank, D. C., Papale, D., Rammig, A., Smith, P., Thonicke, K., van der Velde, M., Vicca, S., Walz, A., and Wattenbach, M.: Climate extremes and the carbon cycle, Nature, 500, 287-295, 2013.

Renton, M. and Poorter, H.: Using log-log scaling slope analysis for determining the contributions to variability in biological variables such as leaf mass per area: why it works, when it works and how it can be extended, New Phytol., 190, 5-8, 2011.

Ringler, M.-E.: Quantifizierung des Wasserhaushaltes unterschiedlich intensiv genutzter Wiesen und Weiden im Alpenraum im Kontext des Klimawandels, Msc. thesis, Technical University of Munich, 2017.

Schindler, U.: A rapid method for measuring the hydraulic conductivity in cylinder core samples from unsaturated soil, Arch. Acker. Pfl. Boden., 24, 1-7, 1980.

Schrader, F., Durner, W., Fank, J., Gebler, S., Pütz, T., Hannes, M., and Wollschläger, U.: Estimating Precipitation and Actual Evapotranspiration from Precision Lysimeter Measurements, Procedia Environ. Sci., 19, 543-552, 2013.
Silva, L. C. R.: From air to land: understanding water resources through plant-based multidisciplinary research, Trends Plant Sci., 20, 399-401, 2015.

Solomon, S., Plattner, G.-K., Knutti, R., and Friedlingstein, P.: Irreversible climate change due to carbon dioxide emissions, P. Natl. Acad. Sci. USA, 106, 1704-1709, 2009.

Tackenberg, O.: A New Method for Non-destructive Measurement of Biomass, Growth Rates, Vertical Biomass Distribution and Dry Matter Content Based on Digital Image AnalysisTackenberg - Image Analysis for Non-destructive Biomass MeasurementTackenberg - Image Analysis for Non-destructive Biomass Measurement, Ann. Bot.-London, 99, 777-783, 2007.

van der Schrier, G., Efthymiadis, D., Briffa, K. R., and Jones, P. D.: European Alpine moisture variability for 1800-2003, Int. J. Climatol., 27, 415-427, 2007.

Viviroli, D., Weingartner, R., and Messerli, B.: Assessing the Hydrological Significance of the World's Mountains, Mt. Res. Dev., 23, 32-40, 2003.

Vogel, A., Fester, T., Eisenhauer, N., Scherer-Lorenzen, M., Schmid, B., Weisser, W. W., and Weigelt, A.: Separating Drought Effects from Roof Artifacts on Ecosystem Processes in a Grassland Drought Experiment, PLOS ONE, 8, e70997, https://doi.org/10.1371/journal.pone.0070997, 2013.

Wang, L., Good, S. P., and Caylor, K. K.: Global synthesis of vegetation control on evapotranspiration partitioning, Geophys. Res. Lett., 41, 6753-6757, https://doi.org/10.1002/2014GL061439, 2014.

Wei, Z., Yoshimura, K., Wang, L., Miralles, D. G., Jasechko, S., and Lee, X.: Revisiting the contribution of transpiration to global terrestrial evapotranspiration, Geophys. Res. Lett., 44, 2792-2801, 2017.

Wieser, G., Hammerle, A., and Wohlfahrt, G.: The Water Balance of Grassland Ecosystems in the Austrian Alps, Arct. Antarct. Alp. Res., 40, 439-445, 2008.

Wohlfahrt, G., Bianchi, K., and Cernusca, A.: Leaf and stem maximum water storage capacity of herbaceous plants in a mountain meadow, J. Hydrol., 319, 383-390, 2006.

Wohlfahrt, G., Hammerle, A., Haslwanter, A., Bahn, M., Tappeiner, U., and Cernusca, A.: Seasonal and inter-annual variability of the net ecosystem $\mathrm{CO}_{2}$ exchange of a temperate mountain grassland: Effects of weather and management, J. Geophys. Res.-Atmos., 113, 1-14, 2008.

Zacharias, S., Bogena, H., Samaniego, L., Mauder, M., Fuß, R., Pütz, T., Frenzel, M., Schwank, M., Baessler, C., ButterbachBahl, K., Bens, O., Borg, E., Brauer, A., Dietrich, P., Hajnsek, I., Helle, G., Kiese, R., Kunstmann, H., Klotz, S., Munch, J. C., Papen, H., Priesack, E., Schmid, H. P., Steinbrecher, R., Rosenbaum, U., Teutsch, G., and Vereecken, H.: A Network of Terrestrial Environmental Observatories in Germany, Vadose Zone J., 10, 955-973, 2011.

Zeppel, M. J. B., Wilks, J. V., and Lewis, J. D.: Impacts of extreme precipitation and seasonal changes in precipitation on plants, Biogeosciences, 11, 3083-3093, https://doi.org/10.5194/bg-113083-2014, 2014. 